\begin{tabular}{|c|c|}
\hline & $\begin{array}{c}\text { International Journal of Engineering \& Technology } \\
\text { Website: www.sciencepubco.com/index.php/IJET } \\
\text { Research paper } \\
\end{array}$ \\
\hline
\end{tabular}

\title{
Reservoir Sediment Inflow Prediction using Integrated Rainfall-Runoff and Discharge-Sediment model
}

\author{
Abdul Razad A.R ${ }^{1 *}$, Sidek L.M ${ }^{2,3}$, Basri H. ${ }^{3}$, Alexander J.L. ${ }^{3}$, Jung K., Sinnakaudan S.K ${ }^{5}$ \\ ${ }^{1}$ Civil Engineering and Geoinformatics Unit, TNB Research Sdn Bhd \\ ${ }^{2}$ Sustainable Energy and Environment Group, Institute of Engineering Infrastructure (IEI), College of Engineering, Universiti Tenaga \\ Nasional \\ ${ }^{3}$ Civil Engineering Department, Universiti Tenaga Nasional \\ ${ }^{4}$ Centre of Expertise, Energy Ventures Division, Tenaga Nasional Berhad \\ ${ }^{5}$ International Water Resources Research Institute, Chungnam National University, Daejon, Republic of Korea \\ ${ }^{6}$ Water Resources Engineering and Management (WAREM), Universiti Teknologi MARA, Pulau Pinang \\ *Corresponding author E-mail: azwin.razad@tnb.com.my
}

\begin{abstract}
Reservoir sedimentation adversely affects both operation and safety of dam. It is important for reservoir manager and operator to predict the incoming sediment inflow into a reservoir to develop sustainable sediment management plan. Continuous sediment monitoring is preferred to estimate total sediment load but it is labor intensive and costly. To cope with these limitations, total sediment inflow into a reservoir is predicted by coupling the runoff from hydrological model and sediment rating curves derived from field sampling dataset. In this research, MIKE NAM rainfall runoff model is used to simulate runoff in Cameron Highlands' catchment, using hydrological data from 1999 to 2012. This model is calibrated and validated using the flow data of Sg Bertam. Field sampling is conducted to measure the Total Suspended Solids (TSS), Bed Load and grab samples at major rivers namely Sg Telom, Sg Habu, Sg Ringlet and Sg Bertam. Sediment rating curves using power function are used to describe the relationship between the total sediment load and discharge. Using this concept, annual total sediment inflow into Ringlet Reservoir from 1999 to 2012 is estimated in the range of 100,000 $\mathrm{m}^{3} / \mathrm{year}$ to 270,000 $\mathrm{m}^{3} /$ year, agreeable to the survey records previously.
\end{abstract}

Keywords: rainfall runoff, sediment rating curves, reservoir sedimentation, integrated

\section{Introduction}

Reservoir sedimentation is a common problem faced worldwide. A comprehensive reservoir sedimentation management requires good understanding on the incoming sediment inflow rate. Estimation of sediment inflow rate involves three major components; prediction of potential sediment yield generated from the catchment, transport rate of sediment through river network and sediment deposition in the reservoir.

First method to predict sediment inflow is based on reservoir survey records. Storage is calculated using either Triangular Irregular Network (TIN), which is simplified using GIS software or conventional cross section method. Using two consecutive survey information, difference in storage indicates sedimentation rate provided that information on sediment removal via dredging, flushing or others is known. However, this method does not provide temporal variation of sediment inflow, but useful for long term sediment management and planning. Main limitation of this method is frequency of survey record, as it is costly to conduct every survey. Another common method to predict reservoir sedimentation rates is using the trap efficiency, which is defined as the ratio between sediment deposition inside the reservoir and sediment inflow into the reservoir. Using the trap efficiency curves, annual sediment inflow can be estimated based on the capacity to annual inflow ratio and type of the reservoir [1] [2].
Reservoir can also be described as the outlet of a catchment. Therefore, the total sediment load into the reservoir is well represented by sediment yield generated at the catchment. There are many models which can simulate sediment yield, based on hydrological processes in the catchment. The simplest model is using Revised Universal Soil Loss Equation (RUSLE) [3] and modified soil loss equation (MUSLE) [4] which quantifies total annual erosion rate and sediment yield generated per storm event. The annual sediment yield is therefore a total sum of sediment yield for each storm events in that particular year. RUSLE calculate total sheet and rill erosion occur in the catchment, which is translated to sediment yield my multiplying the soil loss rate with sediment delivery ratio (SDR).

There are also physically-based hydrological models that allow modelling of hydrological, water quality, sediment and nutrient transport processes in the catchment. Soil and Water Assessment Tool (SWAT) SWAT is a physically distributed hydrological model, capable to simulate sediment and runoff within a catchment on daily time step [5] [6]. It uses the concept of erosion rate calculated using Universal Soil Loss Equation (USLE) and MUSLE, embedded in the model in Geographical Information System (GIS) platform. There are other complex physically-based models available such as Areal Nonpoint Source Watershed Environment Response Simulation (ANSWERS) [7], Water Erosion Prediction Project (WEPP) [8], Pacific Southwest Interagency Committee (PSIAC), Erosion Productivity Impact Calculator (EPIC) [9], Agricultural Non-point Source pollution model (AGNPS) 
[10] and Hydrologic Simulation Program FORTRAN (HSPF) [11]. The use of these physically-based models requires extensive dataset such as topography, soil map, land use, land cover and weather data such as rainfall, temperature, solar radiation and humidity, which are often lacking. Most of the models are usually applicable to agricultural areas and focus on event-based. These models can be also be integrated in GIS platform to expedite the calculation and analysis, with ability to visualize the results in geographically referenced location.

Sediment inflow rate can also be calculated based on continuous sediment monitoring, encompasses of Total Suspended Solids (TSS), Bed Load and discharge measurement at major rivers feeding into the reservoir. Samples taken at site are processed in the laboratory to determine the respective load. Total sediment load is sum of total suspended solid (materials that in suspension along the water column) and bed load that moves along the river bed. However, continuous sampling is costly and laborious. Noncontinuous sampling covering dry and especially wet period can be used to derive sediment-discharge relationship (C-Q) known as rating curve. One key important point is that sediment load is much higher during storm event, and can multiply by many folds in comparison to that of normal flow.

Sediment inflow rate using sediment rating curves have been widely used to estimate sediment load when and where measured data are not available [12] [13]. If the area is equipped with gauging station, then the total sediment load is the sum of daily, hourly or monthly sediment load transported based on the discharge. For ungauged catchment, rainfall runoff model can be used to simulate runoff, to be coupled with sediment rating curves.

Rainfall runoff modelling is categorized into three categories namely; conceptual, black-box (or stochastic) and deterministic model [14]. Black box methods are data driven such as artificial neural network and regression analysis. MIKE NAM [15], HEC HMS [16], Sacramento model, Tank model [17] Runoff routing model (RORB) [18] are the examples of conceptual lumped model, that simplifies the catchment to contain several storages and assigning the relevant parameters on the catchment. Deterministic model or physically based model characterizes the physical processes in the catchment and require large dataset.

Water quality prediction system was developed based on an integrated catchment-coastal model and water quality database [19] while new models that combine Muskingum model and the sediment rating model was used to develop an integrated water discharge-sediment concentration model (WSCM) [20].

Based on the literatures mentioned above, main research gap is in the method to develop of continuous sediment load prediction hydrograph based on daily runoff, with provision on impact of shorter duration runoff. In this study, its main objective is to derive sediment inflow into a reservoir by simulating runoff from the catchment and multiplied it with the sediment rating curves. The sediment rating curves were derived from combination of field sampling, laboratory analyses and statistical non-linear regression. This paper describes the method, analysis and results to predict total sediment inflow into a reservoir in Ringlet, using coupling of rainfall-runoff model and sediment-discharge relationship.

\section{Study area}

Cameron Highlands is located in the state of Pahang, near the mountain range of Peninsular Malaysia. The area is an active highland agriculture area and famous tourist attraction. Cameron Highlands is also a home to seven hydro power stations owned and operated by the national utility company, Tenaga Nasional Berhad (TNB). With the total installed capacity of $262 \mathrm{MW}$, the scheme is an important asset to TNB due to it being one of the sources of green energy [21].

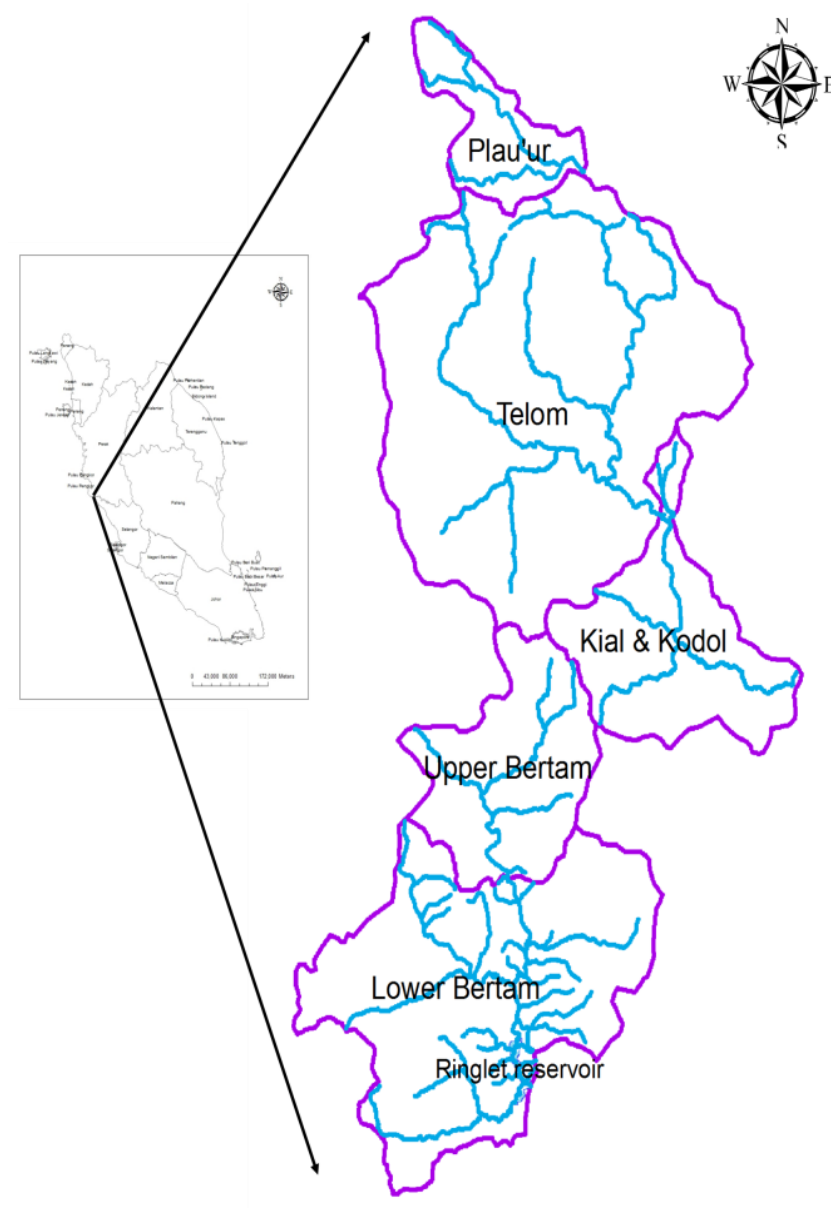

Fig 1: Catchment of Cameron Highlands

Ringlet Reservoir is multipurpose reservoir located in Cameron Highlands, mainly used for hydropower and flood control. The total catchment area that drains into Ringlet is $180 \mathrm{~km}^{2}$, divided into two (2) major catchment of Bertam and Telom. Major rivers feeding into Ringlet are Sg Ringlet, Sg Bertam, Sg Habu and Sg Telom. Most of these rivers are high gradient with slopes between $2 \%$ to more than $10 \%$ (Toriman et al, 2010). The area is hilly with steep slopes, as $26 \%$ of the terrain of is steeper than $25^{\circ}$ and $60 \%$ of the land is steeper than $20^{\circ}$ [22]. Average annual rainfall of the area is more than $2,800 \mathrm{~mm}$, with average of 2 out 3 days raining. Fig 1 illustrates the location Ringlet Reservoir, and major rivers draining into it.

Prior to the completion of the hydropower scheme, most of the areas in Cameron Highlands were covered in forest and the sediment concentrations in the rivers were not very high. Changes in land use in Cameron Highlands from 1947 to 2010 have been significant whereby forest area has reduced by $33 \%$ while agriculture has risen by $18 \%$. Tea and scrub forest maintain at $7 \%$ of total area [21]. However, it is believed based on site observation that agricultural area has occupied more than the reported value.

Bathymetry surveys, site observation and operational difficulties faced by the reservoir operator indicated that the sedimentation rate is high. As part of the sediment management plan for the scheme, sediment inflow rate is estimated based on rainfall runoff modelling and sediment monitoring programme.

\section{Methodology}

There are two main methods adopted for this research, namely rainfall runoff modelling to derive daily runoff variation at major feeder rivers; and development of sediment-discharge rating curves based on sampling and laboratory analyses. 


\subsection{Rainfall runoff model}

The objective of the rainfall runoff modelling is to simulate runoff variation on long term basis at major rivers flowing into Ringlet Reservoir, based on certain hydrological parameters of the catchment. MIKE NAM rainfall-runoff model was used to derive the runoff hydrographs generated by the contributing sub-catchments of Cameron Highlands. MIKE NAM is a parametric, lumped hydrologic model that simulates the land phase of the hydrologic cycle. Thiessen polygon was used to distribute rainfall to the catchment. This model is described as four different tanks and interrelated storages and their corresponding flows is shown in Fig 2.

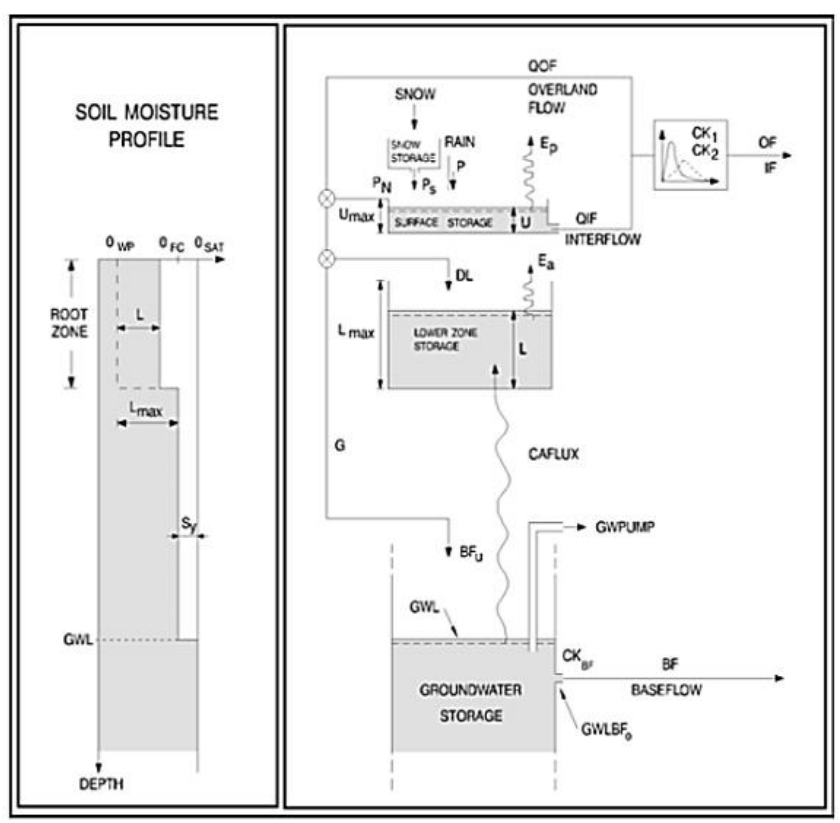

Fig 2: NAM model structure [23]

Model was prepared by digitizing the catchment of Cameron Highlands into several sub-catchments using GIS. Input data required to set up MIKE NAM include land use, rainfall, evaporation, topography, and stream flow data for calibration. In this model, five (5) rainfall stations and one (1) weather station were used, using complete ten (10) years of data available from 1999 to 2012. Details of the sub-catchment is shown in Table $\mathbf{1}$.

\begin{tabular}{|c|c|c|c|c|}
\hline \multicolumn{5}{c}{ Table 1: Summary of sub-catchment } \\
\hline Catchment & River & Sub catchment & $\begin{array}{c}\text { Area } \\
\left(\mathrm{km}^{2}\right)\end{array}$ & $\begin{array}{c}\text { Cumulative } \\
\text { Area }\left(\mathrm{km}^{2}\right)\end{array}$ \\
\hline Bertam & Bertam & Upper Bertam & 21 & \\
& & Lower Bertam & 4.3 & \\
& & Middle Bertam & 13 & \\
& Habu & Habu & 19 & \\
& Ringlet & Ringlet & 9.8 & \\
& & Reservoir & 2.8 & 70 \\
Telom & Telom & Telom & 78 & \\
& & Kial \& Kodol & 22 & \\
& \multicolumn{4}{c}{ Plau'ur } \\
\end{tabular}

To determine most suitable NAM parameters, the model must be calibrated against the observed runoff, using a stream flow station 6003 within Upper Bertam sub-catchment. Calibration was conducted using flow data from 1999 to 2006 , followed by validation for year 2010 to 2012, as shown in Fig 3.

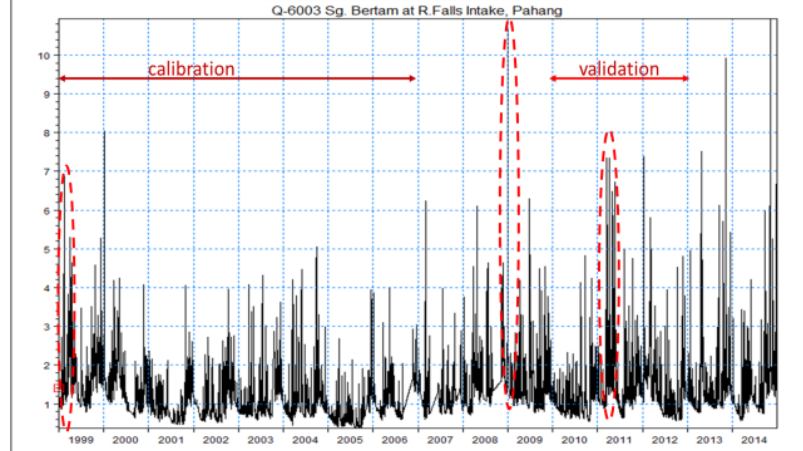

Fig 3: Calibration and validation period used in the model for $\mathrm{Sg}$ Bertam

The calibration was done by manual adjustment of the parameters such that the simulated discharge agree to the observed discharge. The reliability of MIKE NAM is evaluated based on water balance (\%PBIAS) and Nash-Sutcliffe Efficiency (NSE) [24]. It is important to note that to achieve good calibration, good rainfall dataset representative of the sub-catchment is needed. Once the model was calibrated, MIKE NAM was used to simulate the inflows from various sub-catchments, using the calibrated parameters. Summary of the key parameters and their calibrated values are explained in Table 2.

Table 2: Summary of NAM calibrated parameters

\begin{tabular}{|c|c|c|c|c|}
\hline Parameters & Description & $\begin{array}{l}\text { Lower } \\
\text { Bound }\end{array}$ & $\begin{array}{l}\text { Upper } \\
\text { Bound }\end{array}$ & $\begin{array}{l}\text { Final } \\
\text { Value }\end{array}$ \\
\hline $\mathrm{U}_{\max }(\mathrm{mm})$ & $\begin{array}{l}\text { Maximum water con- } \\
\text { tent in surface storage }\end{array}$ & 10 & 20 & 15.1 \\
\hline $\mathrm{L}_{\max }(\mathrm{mm})$ & $\begin{array}{c}\text { Maximum water con- } \\
\text { tent in the root zone } \\
\text { storage }\end{array}$ & 100 & 300 & 171 \\
\hline CQOF & $\begin{array}{c}\text { Overland flow runoff } \\
\text { coefficient }\end{array}$ & 0.1 & 1 & 0.132 \\
\hline CKIF (hr) & $\begin{array}{c}\text { Time constant for } \\
\text { interflow }\end{array}$ & 200 & 1000 & 200 \\
\hline $\mathrm{CK}_{1,2}(\mathrm{hr})$ & $\begin{array}{c}\text { Time constant for } \\
\text { routing interflow and } \\
\text { overland flow }\end{array}$ & 1 & 50 & 4.11 \\
\hline TOF & $\begin{array}{l}\text { Root zone threshold } \\
\text { value for overland } \\
\text { flow }\end{array}$ & 0 & 0.99 & 0.0128 \\
\hline TIF & $\begin{array}{l}\text { Root zone threshold } \\
\text { value for interflow }\end{array}$ & 0 & 0.99 & 0.409 \\
\hline TG & $\begin{array}{c}\text { Root zone threshold } \\
\text { for groundwater re- } \\
\text { charge }\end{array}$ & 0 & 0.99 & 0.959 \\
\hline CKBF (hr) & $\begin{array}{l}\text { Base flow time con- } \\
\text { stant }\end{array}$ & 1000 & 5000 & 2521 \\
\hline
\end{tabular}

\subsection{Development of sediment-discharge rating curves}

To develop sediment-discharge relationship, comprehensive sampling, laboratory and statistical analyses are necessary covering whole range of flow of the river section. Four (4) main rivers feeding into Ringlet are selected as sampling location, namely Sg Habu, Sg Ringlet, Sg Bertam and Sg Telom. Site observations indicated that these rivers have steep slopes, with gravel and sand form major part of bed material. During dry season, flow is limited and it can increase multifold during heavy rainfall, transporting large amount of sediment. Fig 4 illustrates the sampling locations. 


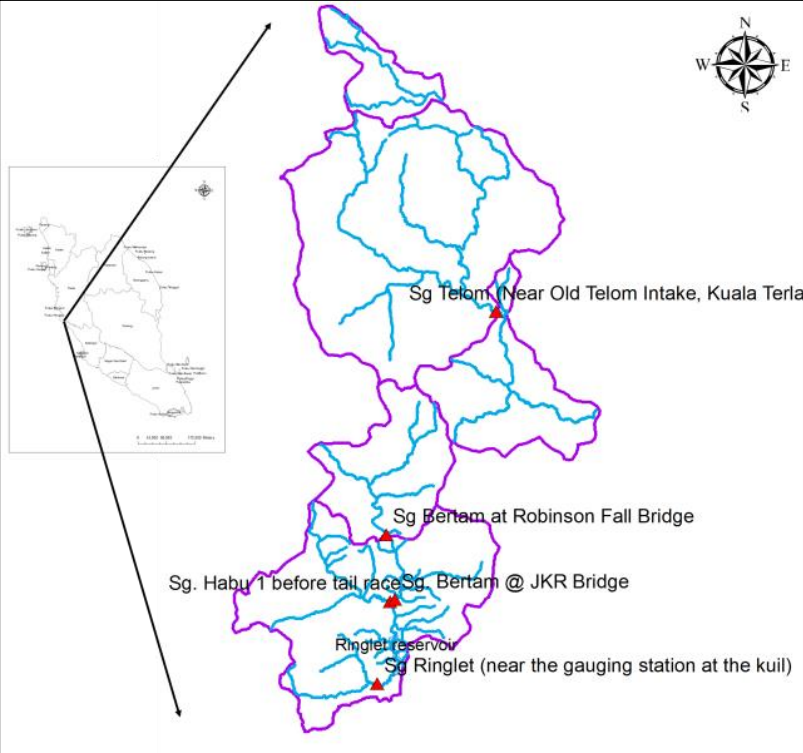

Fig 4: Sediment monitoring locations in Cameron Highlands

Field sampling work for Total Load consists of Total Suspended Solids (TSS) and Bed load was conducted from 2001 to December 2009, covering wet and dry season in Cameron Highlands. TSS sampling has been conducted for much longer period since 1980s. During low flow event (dry season), most of the rivers were shallow allowing the measurements and samples to be taken by wading technique. For medium to high flow data, samples were collected by lowering the equipment from bridges available at the locations. Channel properties such as water surface slope $\left(\mathrm{S}_{0}\right)$, width (B), flow depth $\left(\mathrm{Y}_{0}\right)$ and flow velocity $(\mathrm{V})$ were measured for each river. Discharge measurement is calculated using on $\mathrm{Hy}$ drology Procedure No. 15: River Discharge Measurement by Current Meter [25].

During the sampling, total suspended load (TSS) and bed load were taken. US DH 48 and US DH 59 TSS Sampler were used to obtain TSS samples during low flow and high flow respectively. Helley Smith sampler was used to obtain Bed load $\left(\mathrm{T}_{\mathrm{b}}\right)$. The suspended load concentration was analysed in the laboratory following APHA 2540-D and the bed load concentration was analysed according to the Manual on Operational Methods for the Measurement of Sediment Transport, World Meteorological Organisation - Operational Hydrology Report No 2 [25][26]. A standard Van Veen grab sampler was used to collect bed material. Samples were analysed using or particle size distribution analyses to determine average size of the sediment material. Total sediment load, $\mathrm{T}_{\mathrm{t}}$ is the sum of Suspended Load $\left(\mathrm{T}_{\mathrm{s}}\right)$ and Bed Load $\left(\mathrm{T}_{\mathrm{b}}\right)$. Summary of the data collected and analyses is shown in Table 3.

Table 3: Summary of sediment monitoring data

\begin{tabular}{|c|c|c|c|c|c|}
\hline Rivers & $\begin{array}{c}\text { Dis- } \\
\text { charge, } \\
\mathbf{Q}\left(\mathbf{m}^{\mathbf{3}} / \mathbf{s}\right)\end{array}$ & $\begin{array}{c}\text { Width } \\
\mathbf{B},(\mathbf{m})\end{array}$ & $\begin{array}{c}\mathbf{T}_{\mathbf{s}} \\
(\mathbf{k g} / \mathbf{s})\end{array}$ & $\begin{array}{c}\mathbf{T}_{\mathbf{b}} \\
(\mathbf{k g} / \mathbf{s})\end{array}$ & $\mathbf{T t} \mathbf{( k g / s )}$ \\
\hline Sg. Ring- & $0.51-$ & $7.30-$ & $0.00-$ & $0.00-$ & $0.01-$ \\
let & 37.03 & 9.10 & 159.66 & 0.63 & 160.30 \\
Sg. Habu & $0.51-$ & $7.30-$ & $0.00-$ & $0.00-$ & $0.01-$ \\
& 37.03 & 9.10 & 159.66 & 0.63 & 160.30 \\
Sg Bertam & $0.77-$ & $6.10-$ & $0.01-$ & $0.00-$ & $0.01-$ \\
& 13.75 & 7.20 & 9.31 & 0.33 & 9.64 \\
Sg Telom & $2.43-$ & $7.70-$ & $0.02-$ & $0.00-$ & $0.03-$ \\
& 55.48 & 12.50 & 248.33 & 0.76 & 249.04 \\
\hline
\end{tabular}

Sediment rating curves is best fit line that represent the relationship between total sediment load to discharge, described as power function, power function with constant [12] and linear function [27]. Among all sediment rating curves, power function (as in Equation 1) is the most common to describe the average relation between streamflow (Q) and suspended sediment concentration (SSC) or sediment load for a certain location [28]. To develop the sediment rating curve, total load data was plotted against dis- charge, as x-y scatter plot in Excel. Regression line using power function, was derived using the non-linear regression function embedded in the XLSTAT module. Typical equation is shown in Equation 1 below. Performance of each regression was evaluated using Nash-Sutcliffe Efficiency Index (NSE) to ensure the accuracy of the relationship derived.

$\mathbf{Q}_{\mathrm{s}}=\mathbf{a} \mathbf{Q}^{\mathbf{b}}(\mathbf{1})$

\subsection{Prediction of total sediment inflow}

Inflow simulated using MIKE NAM is tabulated and multiplied with the associated coefficient derived from the sediment discharge relationship. Table $\mathbf{4}$ describes tabulation of total sediment load on daily basis, which is then summed up to generate yearly total.

Table 4: Tabulation of total sediment load

\begin{tabular}{|c|c|c|c|c|c|}
\hline $\begin{array}{c}\text { Date } \\
\text { Time }\end{array}$ & $\begin{array}{c}\text { Q } \\
\text { Ber- } \\
\text { tam } \\
\left(\mathrm{m}^{3} / \mathrm{s}\right)\end{array}$ & $\begin{array}{c}\text { Q } \\
\text { Ring- } \\
\text { let } \\
\left(\mathrm{m}^{3} / \mathrm{s}\right)\end{array}$ & $\begin{array}{c}\text { TL Bertam } \\
(\text { tonnes/da } \\
\mathrm{y})\end{array}$ & $\begin{array}{c}\text { TL Ringlet } \\
\text { (tonnes/da } \\
\mathrm{y})\end{array}$ & $\begin{array}{c}\text { Total daily } \\
\text { (tonnes/da } \\
\mathrm{y})\end{array}$ \\
\hline $1 / 1 / 1999$ & 2.3 & 1.3 & 82.3 & 212.7 & 295.0 \\
$2 / 1 / 1999$ & 1.652 & 0.454 & 40.4 & 41.6 & 82.0 \\
$3 / 1 / 1999$ & 1.302 & 0.183 & 24.2 & 10.2 & 34.4 \\
$4 / 1 / 1999$ & 1.125 & 0.225 & 17.7 & 14.0 & 31.7 \\
$5 / 1 / 1999$ & 1.088 & 0.285 & 16.5 & 20.2 & 36.7 \\
$6 / 1 / 1999$ & 1.018 & 0.096 & 14.3 & 3.7 & 18.0 \\
$7 / 1 / 1999$ & 0.982 & 0.052 & 13.2 & 1.4 & 14.7 \\
$8 / 1 / 1999$ & 0.96 & 0.028 & 12.6 & 0.6 & 13.2 \\
\hline
\end{tabular}

\section{Results and discussion}

Results are divided into three main components; 1) derivation of inflow hydrographs at main rivers feeding into Ringlet Reservoir and 2) derivation of sediment rating curves for each rivers and 3) calculation of annual sediment load. These results were then verified based on the dredging and survey records of Ringlet Reservoir.

\subsection{Flow simulation at major feeder rivers}

The calibration and validation results for continuous period of 1999 to 2006 and 2010 to 2012 using stream flow data at Sg Bertam is illustrated in Fig 5 and Fig 6 respectively, with NSE value of 0.663 and 0.569 respectively. NSE value of more than 0.5 indicates good calibration [29].

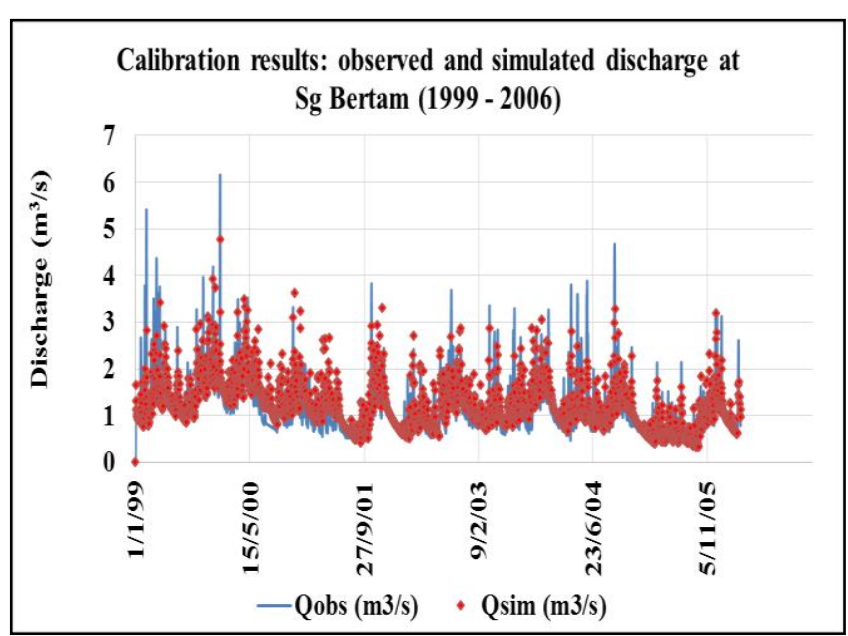

Fig 5: Calibration of observed and simulated flow at Sg Bertam (19992006) 


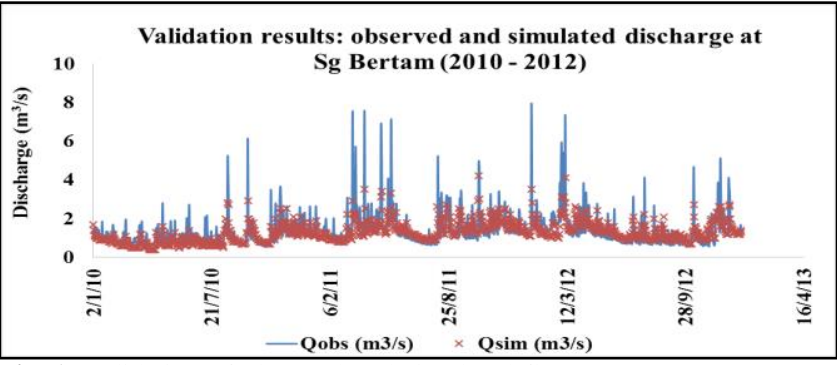

Fig 6: Validation of observed and simulated flow at Sg Bertam (2010 2012)

Based on calibration and validation results, MIKE NAM is reliable to model the rainfall - runoff process in Cameron Highlands. The NAM parameters obtained from the calibration process were used to simulate daily runoff at the respective rivers $\mathrm{Sg} \mathrm{Habu}, \mathrm{Sg}$ Ringlet, Sg Bertam and total average daily inflow into Ringlet Reservoir, as shown in Fig 7 below. From the simulation, average daily inflow into Ringlet reservoir is $6.55 \mathrm{~m}^{3} / \mathrm{s}$, with maximum of $21 \mathrm{~m}^{3} / \mathrm{s}$.

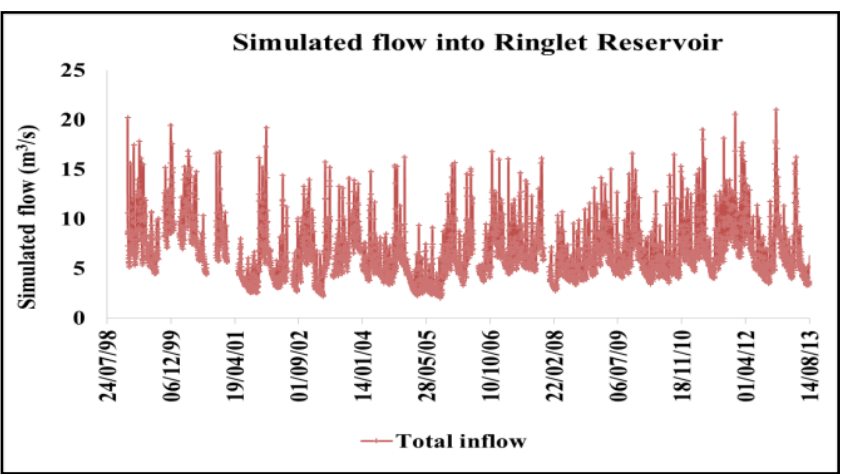

Fig 7: Long term simulated daily inflow into Ringlet Reservoir (19992012)

\subsection{Sediment - discharge rating curves}

Sediment - discharge rating curves were developed using power function, to relate Total Load to discharge. Typical plot of Total sediment load to discharge is shown in Fig 8. Total load is strongly correlated to discharge for all rivers $(p<0.05)$.Performance of each equation is assessed based on NSE values, of which NSE approaching 1 indicated higher accuracy to match the observed measurement. All the rating equation performed well with the observed data, as the NSE value are higher than 0.65 [29]. The sediment rating curves fit the power function with high $\mathrm{R} 2>0.75$.

Table 5 summarises the total load rating curves for each rivers. At equivalent discharge, $\mathrm{Sg} \mathrm{Habu}$ has the ability to transport higher sediment compared to the rivers in Cameron Highlands. Grab samples indicated that the bed material is generally sand. The rating curves also show that rivers in Cameron Highlands generally transport more sediment as compared to other rivers in Malaysia.

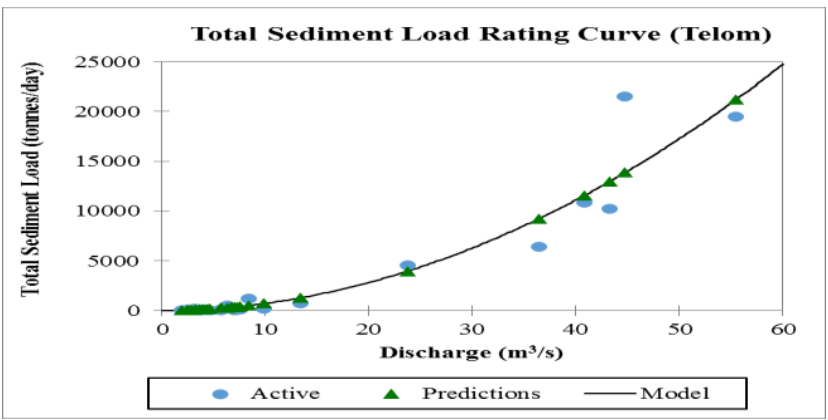

Fig 8: Typical plot of Total Sediment Load to Discharge
Table 5: Total load rating curves derived for rivers flowing into Ringlet Reservoir

\begin{tabular}{|c|c|c|}
\hline River & $\begin{array}{c}\text { Rating curves equation } \\
\left(\mathrm{Qs}=\mathrm{aQ}^{\mathrm{b}}\right)\end{array}$ & $\begin{array}{c}\text { Nash Sutcliffe } \\
\text { Efficiency Index } \\
(\mathrm{NSE})\end{array}$ \\
\hline Sg Ringlet & $\mathrm{Q}_{\mathrm{s}}=141.5993 \mathrm{Q}^{1.551}$ & 0.84 \\
Sg Bertam & $\mathrm{Q}_{\mathrm{s}}=7.0787 \mathrm{Q}^{2.53025}$ & 0.66 \\
Sg Habu & $\mathrm{Q}_{\mathrm{s}}=167.2625\left(\mathrm{Q}^{1.2269}\right.$ & 0.99 \\
Sg Telom & $\mathrm{Q}_{\mathrm{s}}=7.62699\left(\mathrm{Q}^{1.9748}\right.$ & 0.92 \\
\hline
\end{tabular}

Sediment rating curves equations were multiplied with the simulated flow of the rivers feeding into Ringlet Reservoir to obtain the total sediment load. Using the specific density of $1.62 \mathrm{ton} / \mathrm{m}^{3}$, the total sediment load flowing into Ringlet Reservoir is estimated at 100,000 to slightly more than $200,000 \mathrm{~m}^{3} /$ year based on long term simulated runoff from 1999 to 2012. Table 6 summarises total annual sediment load based on the coupling of daily discharge and sediment rating equation.

Table 6: Estimation of annual sediment inflow into Ringlet

\begin{tabular}{|c|c|c|c|}
\hline Year & $\begin{array}{c}\text { Annual Load } \\
\text { (tonnes) }\end{array}$ & $\begin{array}{c}\text { Annual load } \\
\left(\mathrm{m}^{3}\right)\end{array}$ & $\begin{array}{c}\text { Annual load (effect } \\
\text { of time scales, ratio } \\
\text { of daily to hourly) }\end{array}$ \\
\hline 1999 & 335,562 & 207,137 & 269,278 \\
2000 & 296,422 & 182,977 & 237,870 \\
2001 & 186,368 & 115,042 & 149,555 \\
2002 & 172,023 & 106,187 & 138,043 \\
2003 & 219,785 & 135,670 & 176,371 \\
2004 & 175,720 & 108,469 & 141,010 \\
2006 & 231,225 & 142,731 & 185,550 \\
2007 & 243,474 & 150,293 & 195,381 \\
2009 & 243,499 & 150,308 & 195,400 \\
2010 & 187,358 & 115,653 & 150,349 \\
2011 & 288,240 & 177,926 & 231,304 \\
2012 & 306,654 & 189,293 & 246,081 \\
\hline
\end{tabular}

\subsection{Verification}

Annual sediment load predicted using rainfall runoff and sediment rating curves are compared with the bathymetry survey and dredging record. Survey by TNB in 2007 indicated that the total sediment inflow is between 150,000 to $250,000 \mathrm{~m}^{3} / \mathrm{year}$. This is agreeable to annual estimation of $139,712 \mathrm{~m}^{3} /$ year using land use data of 2006 [30]. However, review on methods to predict sediment inflow into reservoir highlighted that adjustment is needed if using daily flow [31]. Sediment load is much higher using shorter duration flow such as hourly or 30minute, whereby a factor larger than 1 is applied to the annual estimate calculated using daily flows. This is even more important especially in Cameron Highlands, whereby sediment load is responsive to sudden surge of flow. Pergau dam feasibility study used factor of 1.30 for annual estimation using daily flow [32], while Pahang-Selangor water transfer used ratio of 1.20 [33]. Applying the same concept in this study, therefore the annual estimate range between 138,000 to $270,000 \mathrm{~m}^{3} /$ year, which is less than dredging record of an average $300,000 \mathrm{~m}^{3} /$ year.

\section{Conclusion}

There are many methods to predict sediment inflow into a reservoir such as sediment yield modelling, daily runoff-sediment rating curve, erosion modelling, and fluvial monitoring and bathyme- 
try survey. Some methods are labour intensive and costly. To derive the spatial and temporal variation of sediment load into a reservoir, the use of integrated runoff - sediment rating was explored in this study. In this study, its main objective is to derive sediment inflow into a reservoir by simulating runoff from the catchment and multiplied it with the sediment rating curves. MIKE NAM rainfall runoff modelling was used to simulate daily runoff variation at major rivers in Cameron Highlands, such as $\mathrm{Sg}$ Ringlet, Sg Habu, Sg Bertam and Sg Telom. Calibration and validation achieved good results, with NSE $>0.66$. Based on the simulation results from 1999 to 2012, average daily inflow into Ringlet Reservoir is $6.55 \mathrm{~m}^{3} / \mathrm{s}$. Sediment monitoring conducted at major rivers were used to derive sediment rating curves, in the form of power function. Using the simulated runoff, daily sediment load at each sub-catchment was computed and summed to derive the annual sediment load. Using daily simulated runoff, annual sediment load is estimated between 100,000 to $200,000 \mathrm{~m}^{3} /$ year. However, it is known that sediment is mostly transported during high flow. Therefore, taking into account the effect of timescales or ratio between daily to hourly runoff, the total annual sediment load is estimated to be in the range of 138,000 to almost 270,000 $\mathrm{m}^{3} /$ year. This prediction of annual sediment inflow can be used by the reservoir manager to plan for the most suitable sediment management.

\section{Acknowledgement}

Author would like to express gratitude to Tenaga Nasional Berhad and TNB Research Sdn Bhd for the research fund to conduct this project. The information contained in this paper is purely based on research work and specifically for research purpose; it does not represent opinion of Tenaga Nasional Berhad and its subsidiaries.

\section{References}

[1] Brune, GM (1953). Trap Efficiency of Reservoirs. Trans. Am. Geophysical Union, 34 (3), 407-418

[2] Churchill, MA (1948). Discussion of Analysis and use of reservoir sedimentation in: Federal Inter-Agency Sedimentation Conference, edited

[3] Renard, KG (1997). Predicting Soil Loss: A Guide to Conservation Planning with the Revised Soil Loss Equation (RUSLE). Handbook, vol. 703. US Dept. Agriculture, Washington DC, USA

[4] Williams, JR (1975). Sediment-yield prediction with universal equation using runoff energy factor. In Present and prospective technology for predicting sediment yield and sources: Proceedings of the sediment-yield workshop, USDA Sediment Lab., Oxford MS, November 28-30 1972. ARS-S-40, 244-252

[5] Arnold, JG and Fohrer, N. (2005), SWAT2000: Current capabilities and research opportunities in applied watershed modeling. Hydrology. Process, 19:563-572

[6] Gassman, PW, Reyes, M, Green, CH and Arnold, JG (2007). The Soil and Water Assessment Tool: Historical development, applications, and future directions. Trans. ASABE 50(4): 1211- 1250

[7] Beasley, DB, Huggins, LF and Monke, EJ. (1980). ANSWERS: a model for watershed planning. Transactions of the American Society of Agricultural Engineers 23: pp. 938-44.

[8] Nearing, M., Foster, G, Lane, L., and Finkner, S. (1989) A processbased soil erosion model for USDA-Water Erosion Prediction Project technology, T. Am. Soc. Agr. Biol. Eng., 32, 1587-1593.

[9] Jones, C, Dyke, P, Williams, J, Kiniry, J., Benson, V, and Griggs, R.(1991) EPIC: an operational model for evaluation of agricultura sustainability, Agr. Syst., 37, 341-350, 1991

[10] Young, RA., Onstad, C, Bosch, D, and Anderson, WP (1989) AGNPS: A nonpoint-source pollution model for evaluating agricultural watersheds, J. Soil Water Conservation., 44, 168-173

[11] Bicknell, B R, Imhoff, JC, Kittle, JL, Jobes, TH, Donigian, AS (2004) HSPF Version 12 User's Manual; AQUA TERRA Consultants: Mountain View, CA, USA

[12] Asselman, NEM (2000). Fitting and Interpretation of Sediment Rating Curves. Journal of Hydrology. 234, 228-248.
[13] Horowitz, AJ (2003). An evaluation of sediment rating curves for estimating suspended sediment concentrations for subsequent flux calculations. Hydrological Processes,vol.17, no.17, pp.3387-3409

[14] Gosain, AK, Mani, A and Dwivedi, C (2009). Hydrological Modelling-Literature Review. Climawater, Report No.1

[15] Nielsen SA and Hansen E. (1973). Numerical simulation of the rainfall runoff processes on a daily basis. Nordic Hydrology [Online]. 4(3), pp. 171-190. Available: http://www.iwaponline.com/nh/004/nh0040171.htm

[16] US Army Corps of Engineers (2001). Hydrologic Modeling System HEC-HMS: User's Manual:, Hydrologic Engineering Center, Washington DC, USA

[17] Sugawara, M. (1995). Tank model. Computer Models of Watershed Hydrology. Vijay P. Singh (ed), LA, USA: 165-214.

[18] Mein, RG, Laurenson, EM and McMahon, TA (1974). Simple nonlinear model for flood estimation, Journal of the Hydraulics Division, Ed. New York, USA, American Society of Civil Engineers, Vol. 100

[19] Bedri, Z. Corkery, A. and O’Sullivan, JJ (2014). Integrated Catchment-Coastal Modelling System for Real-Time Water Quality Forecasts. Environmental Modelling \& Software 61. 458-476

[20] Choudhury, P and Sil, BS (2010). Integrated Water and Sediment Flow Simulation and Forecasting Models for River Reaches, Journal of Hydrology, Volume 385, 313-322.

[21] Abdul Razad, A., Abbas, A.R., Alexander, JL and Mohd Radzi, MR (2011). Design of Effective Sediment Entrapment Basin, 3rd International Conference on Managing Rivers in the 21st Century, Penang, Malaysia

[22] Abdul Razad, AZ, Alexander, JL, Sidek, LM and Basri, H. (2016) Sediment inflow prediction towards effective reservoir sedimentation management. International Conference on Hydropower and Dams (HYDRO 2016), Montreaux, Switzerland.

[23] DHI. (2009). MIKE 11: A Modeling System for Rivers and Channels, Reference Manual, Danish Hydraulic Institute, Denmark.

[24] Nash, JE, and Sutcliffe, JE. (1970). River flow forecasting through conceptual models: Part I. A discussion of principles. J. Hydrology. 10(3): 282-290

[25] American Public Health Association (APHA), American Water Works Association (AWWA), and Water Environment Federation (WEF) (1995). 2540 D: Total suspended solids dried at 103 - 105C. In A. D. Eaton, L.S. Clesceri, and A. E. Greenberg (Eds.), Standard Methods for the Examination of Water and Wastewater, $19^{\text {th }}$ Edition, Washington, D.C.

[26] Department of Irrigation and Drainage Malaysia (DID). (2003) River sediment data collection and analyses. Final Report, Vol III, Kuala Lumpur, Malaysia

[27] Tananaev, NI. (2014). Fitting sediment rating curves using regression analysis: a case study of Russian Arctic rivers, 367, 11-14.

[28] Wang, J, Ishidaira, H., Sun, W., \& Ning, S. (2013). Development and interpretation of new sediment rating curve considering the effect of vegetation cover for Asian basins. The Scientific World Journal

[29] Moriasi, DN, Arnold, JG, Van Liew, MW, Bingner, RL, Harmel, RD and Veith, TL (2007) Model evaluation guidelines for systematic quantification of accuracy in watershed simulations, Transactions of the ASABE 50 (3), 885-900

[30] Alexander, JL., Soo, HT, Sidek, LM, Desa, M. N. and Julien, P.Y (2011). Soil erosion modeling using RUSLE and GIS at Cameron Highlands, Malaysia. $3^{\text {rd }}$ International Conference on Managing Rivers in the 21 st Century, Penang, Malaysia, December

[31] Heng, H.H. and Hii, C.P. (2011) 'Review of reservoir sediment inflow estimate methodology: a case study of Malaysian River', Int. J. Hydrology Science and Technology, Vol. 1, Nos. 3/4, pp.224251.

[32] SMEC/SMHB (1988) 'Pergau hydroelectric project: feasibility study', Vol. 3, Hydrology, Final report, LLN and EPU, Government of Malaysia

[33] Nippon Koei/SMHB (NK/SMHB) (2000) 'Pahang-Selangor raw water transfer project engineering services and detailed engineering design: additional reinforcement study report part 2.1 hydrological report', Jabatan Kerja Raya, Government of Malaysia

[34] Hafiz I, Nor NDM, Sidek LM, Basri H, Hanapi M.N, Livia L, (2013), Application of Integrated Flood Analysis System (IFAS) for Dungun river basin,IOP Conference Series: Earth and Environmental Science, 16(1), Article number 012128.

[35] Hafiz, I, Sidek, LM, Basri, H., Fukami, K., Hanapi, MN, Livia, L and Jaafar, AS (2015), Integrated flood analysis system (IFAS) for Kelantan river basin, IEEE $2^{\text {nd }}$ International Symposium on Tele- 
communication Technologies, Article number 7238196, pp. 159 162.

[36] Abdul Razad, AZ, Mohd Sidek, L, Luis Alexander, JL and Sinnakaudan SK (2017), Assessment of selected sediment transport equations for rivers in highland agricultural area, $4^{\text {th }}$ NATGAD conference

[37] Abdul Razad, AZ, Mohd Sidek, L, Alexander, JL and Mohamed, TA (2017), Estimation of Sediment Inflow into a Reservoir using Combined Approach of Rainfall - Runoff Modelling and Sediment Transport Assessment, $37^{\text {th }}$ IAHR World Conference 